\title{
Backshoring in Light of the Concepts of Divestment and De-internationalization: Similarities and Differences
}

\author{
Michał Młody
}

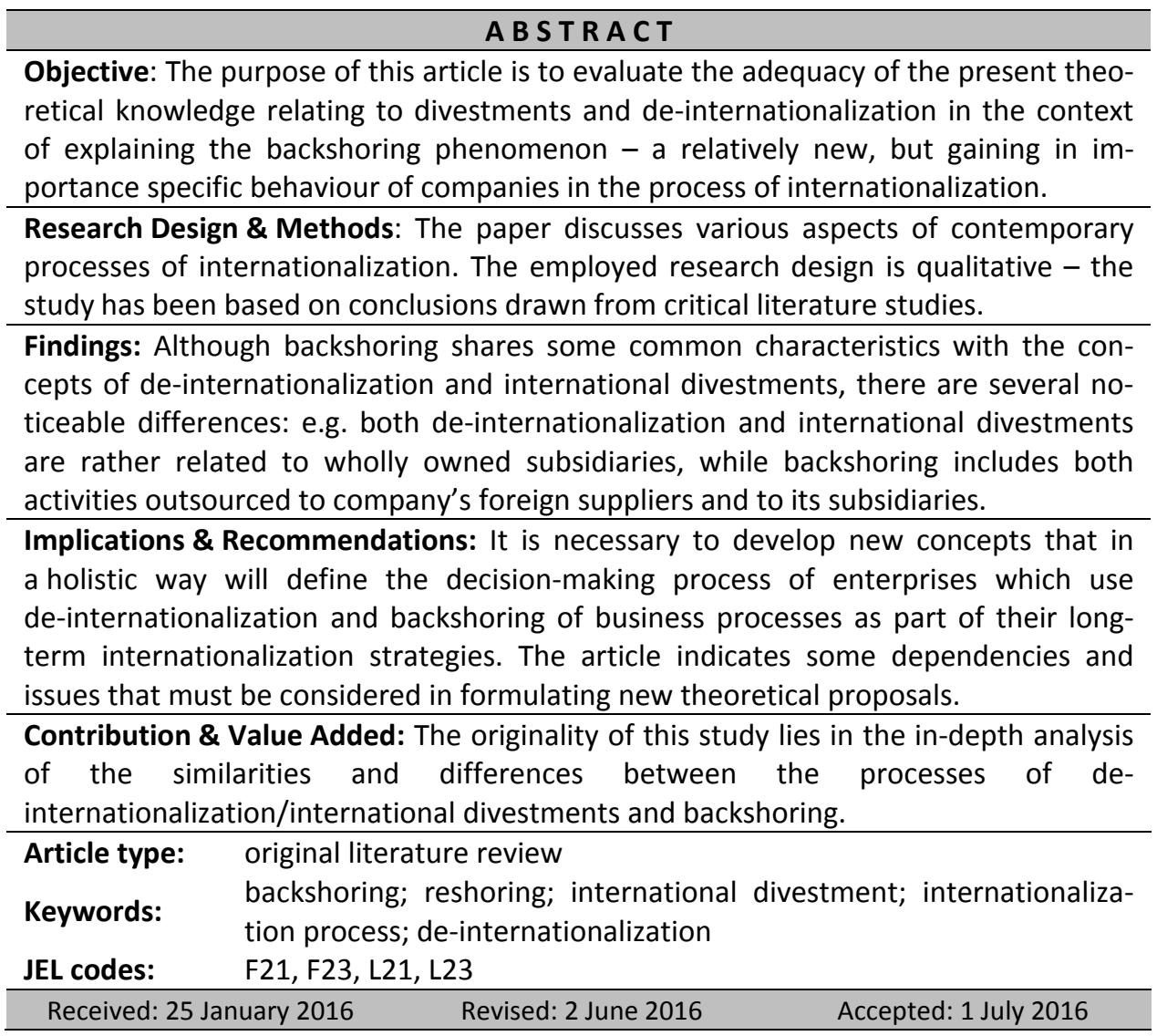

\section{Suggested citation:}

Młody, M. (2016). Backshoring in Light of the Concepts of Divestment and De-internationalization: Similarities and Differences. Entrepreneurial Business and Economics Review, 4(3), 167-180, DOI: http://dx.doi.org/10.15678/EBER.2016.040312 


\section{INTRODUCTION}

International business (IB) literature contains multiplicity and diversity of theoretical explanations of motives, courses and consequences of internationalization of enterprises. Such variety results from methodological and content-related reasons. Due to a great plurality of possible paths of internationalization, researchers can focus attention only on selected aspects of operations undertaken by the companies in international markets. Reasons for expansion into foreign markets should be sought in new phenomena in the macro- and competitive environment. Companies create their own, often completely new, development and competitive strategies, taking into account current and future external conditions. Consequently, there is no single universal theory of internationalization, but rather a bundle of complementary concepts that can be applied to explain the internationalization processes of different types of businesses.

First (traditional) theoretical approaches covered the internationalization of production and foreign direct investments, generally undertaken by companies with ownership advantages (resulting from the company's size, experience and possession of unique technology). The concepts which were developed in the last decades of the twentieth century perceived internationalization as a gradual process of increasing the companies' involvement in activities on foreign markets through systematic adequate adjustments in the area of used strategies, available resources and organizational structure (MińskaStruzik \& Nowara, 2014). A common feature of these theoretical concepts is the perception of growing internationalization as a one-way escalating process in which companies use various modes of entering foreign markets.

Meanwhile - as indicated by a number of studies - the economic crisis has forced many international companies to reduce the scale and scope of activities on foreign markets. This is not a new phenomenon - since the 70s companies have been making decisions of withdrawing from foreign operations or changing entry modes. However, the current reconfiguration of international business activities is connected with new factors and circumstances that are not fully inherent in previously known concepts of deinternationalization and international divestments. Simultaneously, backshoring - a specific behaviour of some TNCs (transnational corporations) in the process of internationalization, understood as a partial or total relocation of previously offshored companies' activities to their home countries, is gaining importance in recent years. Therefore, it seems crucial to answer the question to what extent the existing theoretical frameworks are useful to explain the trend of backshoring. Thus the main objective of the article is to evaluate the usefulness of concepts of international divestments and deinternationalization in explaining the backshoring phenomenon. The research has been based on conclusions drawn from in-depth study of literature.

The first section of the article describes the essential ideas of international divestment and de-internationalization. In addition, it presents the basic modes and typology of de-internationalization. Then, the main reasons for decision about deinternationalization are identified. In the next part of the paper different definitions of backshoring are compared and the main types of this phenomenon and motives are highlighted on the basis of the selected empirical research. The discussion section presents the main conclusions and points out the similarities and differences between the 
processes of divestment, de-internationalization and backshoring. The paper ends with some conclusions and implications for further research.

\section{MATERIAL AND METHODS}

The main aim of the article is to evaluate the adequacy of current theoretical knowledge relating to divestments and de-internationalization in the context of the possibility of explaining the backshoring phenomenon. Therefore, the paper focuses on the presentation and evaluation of these phenomena by thoroughly discussed definitions, conditions and motives. Identification of similarities and differences allows to assess the usefulness of concepts of international divestments and de-internationalization in explaining backshoring. Based on a review of literature, it can be concluded that although these theoretical concepts have some features in common, backshoring has some specific characteristics that suggest separate approach to this concept in IB field.

The article is of descriptive character. The most recognized concepts have been selected for the needs of this study. The literature review covers available literature on the subject (in particular academic articles), published before December 2015. Selected academic databases (EBSCO, Emerald, Scopus, Google Scholar), taking into consideration such keywords as: "divestment", "de-internationalization", "reshoring", "backshoring", "onshoring" were employed to identify relevant literature ${ }^{1}$. Besides, considering the same keywords, proceedings of the most important international conferences in the area of international business (e.g. EIBA, AIB) have been analysed. Attention has been paid primarily to academic articles, which focused on the analysis of motives, governance structure of relocated activities and the level of voluntariness of companies that decided to implement these strategies.

\section{LITERATURE REVIEW AND THEORY DEVELOPMENT}

\section{De-Internationalization and Divestments as the Specific Behaviours of Companies on International Markets}

In the current economic reality companies are forced, more than ever, to make decisions regarding effective management of international operations' portfolio, including the reduction of activities in foreign markets. As early as in the 70s researchers' attention has been drawn to foreign divestments (Boddewyn, 1979). Since that moment, divestments have stopped to be perceived only as a failure in terms of conducting operations in foreign markets and have been used in the processes of adapting companies to the changes in their internal and external environment.

Multidimensionality of the processes and the variety of companies, industries and locations create a broad spectrum for studying the phenomenon of divestments (Chow \& Hamilton, 1993). When considering divestments from the perspective of a corporate strategy, a portfolio of foreign operations is considered - the company is analysed in terms of its efficiency and strategic adjustment of resources and products. Operations that are unprofitable and deviating from the company's strategy should be immediately

\footnotetext{
${ }^{1}$ Analysis of a number of media articles referencing to reshoring/backshoring was conducted by Cranfield University (2015), and it indicates a dynamic increase of interest in this topic from 2010.
} 
sold or liquidated (Duhaime \& Grant, 1984). This indicates that the probability of divestment depends largely on the strategy adopted by the company in foreign markets. It is also important whether the company adapts and works on individual foreign markets as a part of a multinational strategy, or the branch is a part of an integrated production network belonging to the global company (it is assumed that foreign affiliates are more vulnerable to divestments).

A divestment may mean a partial reduction of activities in foreign markets or total withdrawal of companies from operations on the market through liquidation, sale of assets, or bankruptcy petition (Burt, Dawson \& Sparks, 2003). In the case of sale, the owner changes, but the foreign branch continues its activities. Liquidation means that a foreign subsidiary of a company ceases to exist (Mata \& Portugal, 2000). Divestments may also be the result of failures on the foreign market, adaptation or restructuring actions taken by the company (aimed at improving the functioning of the whole enterprise) or can be also imposed, e.g. in case of nationalization (Benito, 2005)2.

Typology of divestment processes proposed by Simoes (2005) is based on the two approaches to this phenomena: the reduction of the degree of ownership and the reduction of assets held by the company and its activities. The author distinguished: (i) forced divestments / selling a branch / selling part of the shares (reduction of property, business is conducted with no changes), (ii) a decrease in production / decrease in importance of the branch (reduction of operations, the level of ownership remains unchanged), and (iii) liquidation of a foreign branch / sale of shares and reduction of company's activities (reduction of both the scope of operations and the level of ownership), and (iv) no divestments (no changes in the ownership and business activity).

The concept of de-internationalization has been outlined much later and introduced by Welch and Luostarinen (1988), who believed there was no guarantee that the company that started the process of internationalization would continue it in the future. Similarly, Fletcher (2001) challenges the traditional approach to internationalization as an incremental process, and examines the role of de-internationalization in view of longterm internationalization of the company. According to the author, this process is the opposite of gradual progression and should be analysed in the context of the problems identified during the initial implementation of the original internationalization strategy. A similar approach was presented by Calof and Beamish (1995), who claimed that internationalization is a continuous process to adapt the structure, strategies, resources, and other business operations to the conditions prevailing in the international environment, and de-internationalization is a deliberate reduction in the degree of involvement of companies in international markets.

Benito and Welch (1997), who first developed a conceptual model of deinternationalization, believe that this process applies to all activities, both voluntary and forced, which result in a reduction of activities in the international market. The authors have analysed de-internationalization from three theoretical perspectives: economics,

\footnotetext{
${ }^{2}$ However, Boddewyn (1979) claims that foreign divestment is only a voluntary cessation of business activity or the sale of all or selected parts of the company. Besides, also the definition proposed by Mellahi (2003) is limited to de-internationalization as a voluntary engagement in the process of reducing foreign operations in response to the worsening organizational conditions in the local or international market. Deinternationalization in this approach can be a mean to improve the overall profitability of TNCs.
} 
strategic management and internationalization process management. From the perspective of economics, de-internationalization is examined as a rational response to changes in market and competitive conditions. From the perspective of strategic management, the company decides to conduct de-internationalization on the basis of the analysis of product life cycle and portfolio of activities and resources. In turn, from the point of view of the internationalization process managing, authors point out that the ongoing internationalization process of the company is itself seen as a major barrier for deinternationalization (e.g. due to the increasing involvement of senior management in operations in the international markets).

Turcan (2011) created a typology of de-internationalization processes taking two criteria into account: the degree of de-internationalization and the final result of this process (Figure 1). However, this classification does not take into consideration scale and scope of the reduction of foreign operations and does not take into account the change in degree of ownership of existing activities.

\begin{tabular}{|c|c|c|c|}
\hline & & \multicolumn{2}{|c|}{ De-internationalization continuum } \\
\hline & & Total & Partial \\
\hline \multirow{2}{*}{ 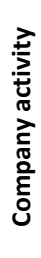 } & Still in business & $\begin{array}{c}\text { Total withdrawal from international } \\
\text { activities/ continuation of activities } \\
\text { on the domestic market }\end{array}$ & $\begin{array}{l}\text { partial withdrawal from activi- } \\
\text { ties on foreign markets }\end{array}$ \\
\hline & Out of business & $\begin{array}{c}\text { Total withdrawal from activities on } \\
\text { foreign markets/ discontinued } \\
\text { operations }\end{array}$ & non-empirical cell \\
\hline
\end{tabular}

Figure 1. Typology of de-internationalization

Source: on the basis of Turcan (2011, pp. 230-232).

Turcan (2011) added the issue of de-internationalization modes to the typology presented above. In accordance with the definition proposed by Benito, Petersen and Welch (2009), he also claimed that forms of conducting business activity in foreign markets include de-internationalization. If the company undertakes a partial deinternationalization, it can reduce the scale of operations in the market or change the form of conducting business to one that requires less workforce or capital commitment. Reduction of operations' scale can be done by reorganization, withdrawal of one of the brands from a given market, or production of older version of the product. In case of changing entry mode in the foreign market, a company may decide to de-invest, defranchise or de-export. A company which decides to de-invest may in turn change the form of business activities, e.g. to franchising, contracting-out or assets sale.

The main difference between divestment and de-internationalization is the possibility to do a multi-dimensional analysis of the phenomenon of de-internationalization. Researches on foreign divestments (and withdrawal from export activities) focus basically on the form of activities, while the scope of the analysis of de-internationalization processes may include other aspects, e.g. a products portfolio or the attractiveness of individual foreign markets. Thus, in relation to the whole company, de- 
internationalization seems to be a much wider concept ${ }^{3}$. Despite these differences, it must be noted that these two processes are characterized by: 1) a voluntary or forced reduction in the degree of company's involvement on foreign markets; 2 ) the complete withdrawal of a company from a foreign market or partial reduction of the involvement on a given market (Reiljan, 2004).

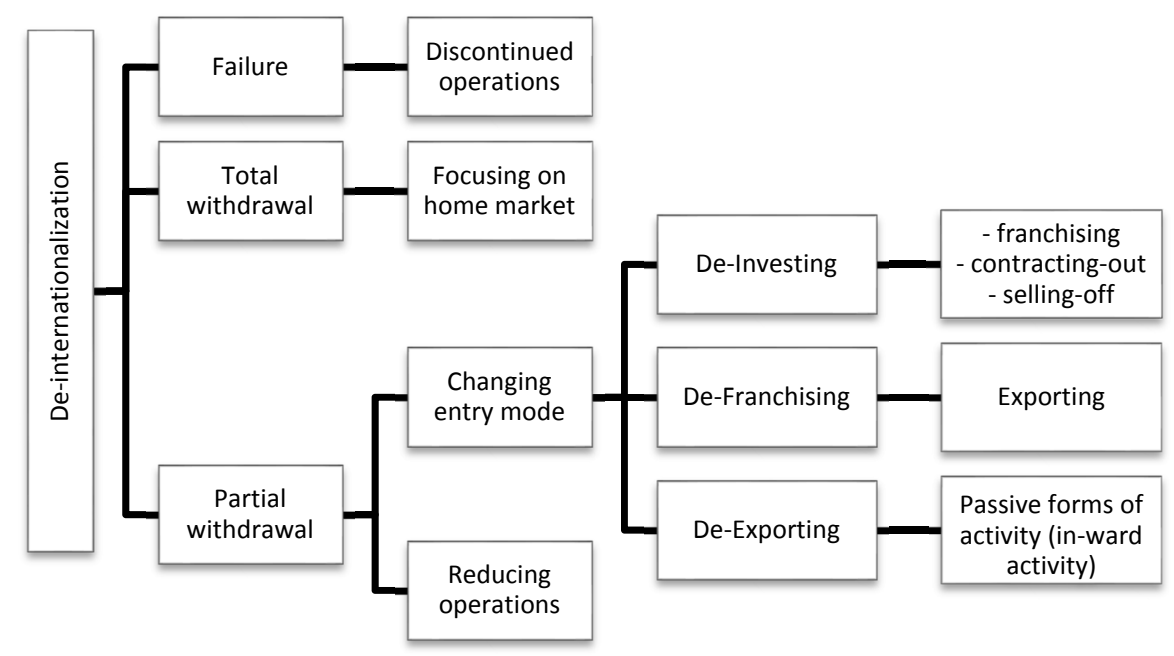

Figure 2. Modes of de-internationalization

Source: Turcan (2011, p. 42).

\section{Motives of De-internationalization}

Reiljan (2004) classified the reasons for de-internationalization basing on the analysis of empirical research on divestments and withdrawal of export activity. She also highlighted four groups of factors influencing the decision to reduce involvement in foreign markets. As she points out, the motives may result from lack of international experience, strategic changes, poor financial results or increase of costs and "other factors".

The group of motives related to lack of experience include, inter alia, insufficient market analysis preceding the process of internationalization, too early / too late started expansion into the foreign markets, lack of information, wrong choice of target market or inappropriate entry mode. A lack of experience in foreign markets may also result in maladjustment of the product and insufficient adaptation to the foreign market requirements. A partial or complete de-internationalization can also result from changes in the business strategy, including, e.g. rationalizing company's activities, focusing on the key areas of company's activities, changes in management, the increase in demand on the domestic market, a shortage of necessary resources (including qualified staff) and consequently limited production capacity or changes in the operation in the given foreign market. In a group of reasons connected with poor financial results or an increase in

\footnotetext{
${ }^{3}$ De-internationalization is sometimes a preparation to re-internationalization. Welch and Welch [2009], while exploring the issue of re-internationalization, have defined it as a process of internationalization of a company, with a temporary withdrawal from a foreign market, finished with a successful comeback.
} 
incurred costs Reiljan (2004) has listed an advancing competitive pressure (in the country of origin, in the host country and in other countries), rising production costs, transportation costs and taxes. Among the "other reasons" the author has pointed out deinternationalization processes of related industries, external shocks, governmental interventions and ownership changes.

Reasons related to the lack of experience are most important at an early stage of expansion into international markets. At a later stage of internationalization, the most important reason for de-internationalization seems to be an increase in costs resulting for example from changes in the economic situation on foreign markets. At the most advanced stages of internationalization, a frequently occurring reason for deinternationalization is reorganization and a change of the company's strategy. As indicated by Mińska-Struzik and Nowara (2014), in the case of de-internationalization of activities resulting from financial or strategic motives, this process is not generally followed by reduction of the involvement in foreign markets, but rather by changes of host markets and/or entry modes.

Often, despite obvious reasons to conduct de-internationalization, the decision on withdrawal from operations in foreign markets is not ultimately adopted. The main reasons for postponing de-internationalization are reluctance to admit a defeat and a large connection of foreign branch with the other activities of the company. The fact is that the decision to withdraw from activities on the foreign market is not easy, especially when making it may be hindered by factors which constitute exit barriers (Porter, 1976).

\section{In Search of the Definition and Motives of Backshoring}

The IB literature have repeatedly called into question the benefits of captive offshoring and offshore outsourcing, noting a big difference between the value of savings initially estimated by the companies and their actual achieved profits (Leibl, Nischler, Morefield \& Pfeiffer, 2009). The debate among researchers, business practitioners and politicians about the need for re-industrialization of developed countries is largely based on expectations that the return of manufacturing companies that have previously moved part of their operations to low-cost countries, will contribute to restoration of (industrial) competitiveness of developed countries (lozia \& Leirião, 2014).

Although the scale of re-industrialization remains limited, the number of companies that have decided to backshore is growing rapidly. It is difficult to accurately assess how common is this phenomenon, as there is no fully reliable data. The problem with estimating the scale of backshoring also stems from the fact that this concept is not clearly defined $^{4}$. Basically, backshoring concerns transfer of business processes, production and services that have been transferred to an offshore (or nearshore) location, back to the country of origin (Arlbjørn \& Mikkelsen, 2014). In other words, backshoring is a form of reshoring, which itself is a reversal of offshoring and can refer simply to change of the location (Gray, Skowronski, Esenduran \& Rungtusanatham, 2013) ${ }^{5}$.

\footnotetext{
${ }^{4}$ In the literature there are also other terms defining backshoring, e.g. „backsourcing”, „insourcing”, ,inshoring”, „on-shoring", ,home-shoring" or "repatriating manufacturing” etc.

${ }^{5}$ Fratocchi et al. (2014) divide reshoring into: back-reshoring - meaning a return to the home country, and near-reshoring - meaning a transfer of business processes to the location close to the home country.
} 
The variety of definitions result from the concentration of authors on various aspects of this phenomenon, although almost all researchers accept that backshoring refers to the earlier delocalized manufacturing processes, regardless of the business model adopted on the foreign market (outsourcing or insourcing). Thus, backshoring covers the case of partial repatriation of offshored production processes ${ }^{6}$ (which may concern a whole foreign branch or some of company's functional areas). One of the basic conditions of backshoring is also the aim of the company to satisfy a demand in the home / local market from the point of view of the parent company ${ }^{7}$. Therefore, it can be generally assumed that backshoring means a strategic, voluntary decision to relocate previously delocalized modules of the value chain to its country of origin, regardless of whether these processes are or will be implemented under their ownership structures or through outsourcing. This phenomenon relates to a physical location, not the ownership itself, which is why manufacturing backshoring can be analysed from different perspectives, and as a result, four possible options of backshoring can be identified. The company can provide a demand for products on the domestic market by:

- Option 1: the transfer of production from its own foreign branch (captive offshoring) to the internal structures of the company on its home market (so-called "in-house backshoring").

- Option 2: the transfer of production activities from its own foreign branch to an external supplier on its home market (backshoring for outsourcing).

- Option 3: the transfer of production activities from the foreign supplier (offshore outsourcing) to the internal structures of the company on its home market (backshoring for insourcing).

- Option 4: the transfer of production activities from the foreign supplier to an external supplier on its home market - the change relates only to geographical boundaries (outsourced backshoring) (Młody, 2015).

The literature indicates some factors that made some companies decide to reconsider their strategies of internationalization and eventually relocate (partially or totally) production processes to the country of origin. Although in recent years a whole range of studies on backshoring has appeared (Arlbjørn and Mikkelsen, 2014; Fratocchi, Di Mauro, Barbieri, Ancarani, Lapadre \& Zanoni, 2014; Kinkel, 2012; Kinkel, 2014; Martínez-Mora \& Merino, 2014; Tate, Ellram, Schoenherr \& Petersen, 2014; Van den Bossche, Gupta, Gutierrez \& Gupta, 2014), comprehensive empirical studies on this phenomenon are very limited.

Backshoring may be an operational action taken to correct previous decisions regarding the relocation of value chain activities, due to e.g. internal or external conditions, or as a part of a long-term strategy (Bals, Tate \& Daum, 2015). According to Kinkel (2014), $80 \%$ of German backshoring activities are classified as operative corrections to managerial decisions whereas $20 \%$ are categorized as strategic adaptations to changing

\footnotetext{
${ }^{6}$ The attention is paid most of all to the backshoring of production processes because of at least two reasons: 1) exit barriers for production processes are generally much higher than in the case of services, 2) offshoring of services, in contrast to offshoring of production, relates to a limited number of locations (India and East-Central Europe among others).

${ }^{7}$ It is hard to imagine production relocation, targeted at Asian markets, from China to e.g. Western European countries for any economic reasons.
} 
environmental conditions (Kinkel, 2014). However, current trend indicates moving away from managerial adaptations to strategic ones (Bals et al., 2015).

It happens that companies carrying out production in foreign locations "forget" about the care of such important aspects as a high quality of products offered on the domestic market and their innovativeness (Arlbjørn \& Mikkelsen, 2014; Van den Bossche et al., 2014). Another important factor is also the made in effect, especially in the context of consumer ethnocentrism (Martínez-Mora \& Merino, 2014; Tate et al., 2014). The tendency of "lean" supply chains and quick reactions to consumers' needs, favours locating production close to the home markets (Kinkel, 2012). Besides, consumers expect quick delivery time, which in the case of transport from Asian countries is not possible, even more so if we consider the issue of minimum orders.

Characteristics of the host country are also often cited as the basis to undertake backshoring, not only because of the increase in cost, but due to such factors as: inadequate infrastructure in host countries, unavailability of skilled manpower, high cost of coordination and control, or low level of protection of intellectual property rights (Kinkel, 2014; Pearce, 2014). Another, sometimes overlooked aspects are the investment incentives in home countries ${ }^{8}$ (Gray et al., 2014; Tate et al., 2014).

In summary, there is a whole range of factors that can motivate managers to take decision to backshore production activities back to home countries. The frequency and strength of these determinants can be influenced by the company's size and financial health, international environment (e.g. oil prices, political stability), the attractiveness of the market of the host (including e.g. market capacity) and the possibility of restoration of a local supply base in close proximity to key customers.

\section{DISCUSSION}

The concepts of divestment, de-internationalization and backshoring presented in the article indicate the fact that company's international activities should be considered in a holistic way, by analysing the motives and conditions of the decisions taken in the context of both directions of internationalization processes. The company cannot introduce backshoring strategy of de-internationalization (effect) if its activities were not previously relocated (cause) ${ }^{9}$. Therefore, de-internationalization is a strategic business decision, aimed at optimizing company's operations. Similarly, backshoring can be interpreted as an action to de facto improve the functioning of the company in the long run.

Based on the above literature review, it can be concluded that backshoring shares some similarities with de-internationalization and international divestments. Given the broad definition of de-internationalization, understood as any action taken by the company (both forced and voluntary), which results in reduction of involvement in activities on foreign markets (Benito \& Welch, 1997), backshoring may be considered even as a certain kind of de-internationalization. On the other hand, these concepts lack several key features of the backshoring phenomenon, such as manufacturing outsourcing

\footnotetext{
${ }^{8}$ Examples of the investment incentives have been described in e.g. World Investment Report 2014 (UNCTAD, 2014, p. 109).

${ }^{9}$ Benito and Welch (1997) have considered whether the particular factors, which cause the level of company's internationalization to rise, work also in the opposite direction, causing and enhancing processes of deinternationalization.
} 
(Fratocchi et al., 2015; Moradlou \& Backhouse, 2015). Significant differences can be seen by analysing the motives of both processes (Table 1). Backshoring should be considered as individual strategic decision of the company, while de-internationalization can be either voluntary or forced (because of e.g. nationalization or government intervention in the host country). Reasons for backshoring may also have a non-financial nature, bound to political issues or consumer ethnocentrism. Factors that affect both deinternationalization, as well as backshoring are, inter alia, rising production costs in host countries, and the difficulty of coordinating operations in foreign markets. According to the analysis, companies, in the case of backshoring, pay close attention to quality, innovativeness and intellectual property protection in host countries - factors that did not constitute generally motives of de-internationalization. Besides, it is noteworthy that investment incentives for foreign operating companies in their home countries can in the future significantly contribute to remodelling of the international manufacturing system.

Table 1. Comparison of key determinants of de-internationalization and backshoring

\begin{tabular}{|c|c|}
\hline De-internationalization & Backshoring \\
\hline $\begin{array}{l}\text { Strategic and financial grounds: } \\
\text { - rationalization of business operations, } \\
\text { - restructuring of the foreign operations portfolio / } \\
\text { strategic repositioning, } \\
\text { - low income derived from operations on a foreign } \\
\text { market, } \\
\text { - increase in the production / logistics costs, } \\
\text { - financial losses / weak financial position of the com- } \\
\text { pany in comparison with competitors operating on the } \\
\text { given market. }\end{array}$ & $\begin{array}{l}\text { Strategic and financial grounds: } \\
\text { - innovativeness - higher in the home } \\
\text { country, } \\
\text { - improvement of products quality, } \\
\text { - the ability to automate production, } \\
\text { - reduction of supply chain risk, } \\
\text { - increase the production / logistics costs } \\
\text { in host countries, } \\
\text { - improving the response to the demands } \\
\text { of consumers / consumer proximity. }\end{array}$ \\
\hline $\begin{array}{l}\text { Market and organizational motives: } \\
\text { - wrong choice of target market or the entry mode, } \\
\text { - mismatch of products - insufficient adaptation to the } \\
\text { foreign market/lack of market research and analyses, } \\
\text { - the loss of a competitive advantage on the foreign } \\
\text { market / increase in competitive pressures, } \\
\text { - unfavourable prospects for development of the indus- } \\
\text { try } \\
\text { - lack of staff resources needed to conduct foreign } \\
\text { operations, } \\
\text { - lack of knowledge and experience, } \\
\text { - insufficient control of foreign affiliates, } \\
\text { - ownership changes, } \\
\text { - government interventions in the host country. }\end{array}$ & $\begin{array}{l}\text { Market and organizational motives / } \\
\text { associated with the production site: } \\
\text { - investment incentives in home coun- } \\
\text { tries, } \\
\text { - the made in effect, } \\
\text { - inadequate infrastructure and adverse } \\
\text { legal conditions in the host countries, } \\
\text { - low level of intellectual property protec- } \\
\text { tion, } \\
\text { - unavailability of skilled manpower in the } \\
\text { host countries, } \\
\text { - the high cost of coordination and con- } \\
\text { trol, } \\
\text { - cultural distance. }\end{array}$ \\
\hline
\end{tabular}

Source: own elaboration on the basis of 1) de-internationalization (Benito, 2005; Benito \& Welch, 1997; Boddewyn, 1979; Duhaime \& Grant, 1984; Hamilton \& Chow, 1993; Reiljan, 2004); 2) backshoring (Arlbjørn \& Mikkelsen, 2014; Fratocchi et al., 2014; Gray et al., 2013; Kinkel, 2012; Kinkel, 2014; Martínez-Mora \& Merino, 2014; Tate et al., 2014; Van den Bossche et al., 2014).

Moreover, while both de-internationalization and divestment refer to the case in which wholly dependent organizational units are partially or completely withdrawn from the market, backshoring may include actions both outsourced to foreign suppliers and insourced within the subsidiaries. Research on de-internationalization does not also 
indicate a transfer of production processes to the company's home country, which is a fundamental condition of backshoring. In summary, it seems that backshoring, despite having some common characteristics with the other two concepts, is characterized by a larger range of other reasons, motives and distinct decision-making processes, and thus, it may constitute an individual concept. This is consistent with the opinion of Fratocchi et. al. (2015) who argue that concept of backshoring has some specific characteristics suggesting a separate conceptualization in the international business literature. Simultaneously, it does not correspond to the structure of equity of divestment proposed by UNCTAD (2013, p. 27), in which backshoring is considered as one of the forms of divestments.

\section{CONCLUSIONS}

The paper has focused on the processes of de-internationalization, divestments and backshoring, to present a multi-dimensional comparative analysis of motives, governance structure of relocated activities and the level of the company's voluntariness in the context of these three processes. Based on the literature studies, it can be concluded that both de-internationalization and backshoring are the next steps of internationalization which aim mainly for the optimization of company's operations. Reduction in the level of internationalization can in fact accelerate the overall development of the company and consequently result in stronger international involvement in long term (Turcan, 2011). Despite some similarities between these phenomena, the concept of deinternationalization (and divestments as a part of it) cannot, however, serve as an explanation of backshoring activities, because of the different scope and motives of enterprises and the level of voluntariness of relocation of manufacturing processes to home countries.

Limitations of the article are related to the still insufficient amount of empirical research on de-internationalization and backshoring, and despite some attempts in recent years to develop a holistic model of internationalization of enterprises the works on a concept, which would cover all current processes in international business are still rare. Future research should focus on the comparison of the motives and circumstances of both the initial relocation and, subsequently, backshoring / de-internationalization of production processes. In particular, these internal conditions, which make companies more susceptible to these processes should be taken into account. This could enable to define in detail the decision-making process in the context of a long-term strategy of internationalization. Besides, future studies should include analysis of dependencies between motives of companies' relocations (using categorisation such as Table 1.) and companies' characteristics like e.g. size of the company, the industry it operates in, governance mode and the specificity of home/host country. Little is also known about the impact of the decisions to backshore/de-internationalise, on the overall financial performance of the company - what are the real costs and profits. Research in this area will be a huge challenge for the scientists because of the necessity of a deep analysis of the broad network of dependencies in complicated paths of location decisions.

In the current economic reality, managers are forced to make strategic decisions on the effective management of portfolios of foreign operations, and therefore companies constantly adjust their structure, resources and strategies to rapidly changing conditions 
within the company and in its external environment. Hence the interest in this subject seems to be extremely important from the point of view of business practice, especially in the context of, among others, volatile international markets, rising wage costs in China and political pressures associated with the trend of re-industrialisation.

\section{REFERENCES}

Arlbjørn, J.S., \& Mikkelsen, O.S. (2014). Backshoring manufacturing: Notes on an important but under-researched theme. Journal of Purchasing and Supply Management, 20(2), 60-62.

Bals, L., Daum, A., \& Tate, W. (2015). From Offshoring to Rightshoring : Focus on the Backshoring Phenomenon. Academy of International Business Insights, 15(4), 3-8.

Benito, G. (2005). Divestment and international business strategy. Journal of Economic Geography, $5(2), 235-251$.

Benito, G., \& Welch, L. (1997). De-Internationalization. Management International Review, 37(2), 7-25.

Benito, G., Petersen, B., \& Welch, L. (2009). Towards More Realistic Conceptualisations of Foreign Operation Modes. Journal of International Business Studies, 40(9), 1455-1470.

Boddewyn, J. (1979). Foreign divestment. Magnitude and factors. Journal of International Business Studies, 10(1), 21-27.

Burt, S., Dawson, J., \& Sparks, L. (2003). Failure in International Retailing: research propositions. International Review of Retail Distribution and Consumer Research, 13(4), 355-373.

Calof, J., \& Beamish, P. (1995). Adapting to Foreign Markets: Explaining Internationalization. International Business Review, 4(2), 115-131.

Chow, Y.K., \& Hamilton, R.T. (1993). Corporate divestment: An overview. Journal of Managerial Psychology, 8(5), 9-13.

Cranfrield University (2015). An Analysis of the UK's Capability to Reshore Production. A White Paper by Cranfield University.

Duhaime, I.M., \& Grant, J.H. (1984). Factor s influencing divestment decision-making: Evidence from a field study. Strategic Management Journal, 5(4), 301-318.

Fletcher, R. (2001). A holistic approach to internationalization. International Business Review. 10(1), 25-49.

Fratocchi, L., Di Mauro, C., Barbieri, P., Ancarani, A., Lapadre, L., \& Zanoni, A. (2014). Manufacturing Reshoring: Threat or opportunity for East Central Europe and Baltic Countries. In A. Zhuplev. \& K. Liuhto (Ed.), Geo-Regional Competitiveness in Central and Eastern Europe, the Baltic Countries, and Russia (pp. 83-118). Hershey, PA: IGI Global.

Fratocchi, L., Ancarani, A., Barbieri, P., Di Mauro, C., Nassimbeni, G., Sartor, M., Vignoli, M., \& Zanoni, A. (2015). Manufacturing back-reshoring as a nonlinear internationalization process. In R. van Tulder, A. Verbeke \& R. Drogendijk (Ed.), The Future of Global Organizing (Progress in International Business Research (pp. 365-403). Emerald Group Publishing Limited.

Gray, J.V., Skowronski, K., Esenduran, G., \& Rungtusanatham, J.M. (2013). The reshoring phenomenon: What supply chain academics ought to know and should do. Journal of Supply Chain Management, 49(2), 27-33.

lozia, E.M., \& Leirião, J.C. (2014). Opinion of the European Economic and Social Committee on the Reshoring of EU industries in the framework of reindustrialization. Retrieved on January 10, 2016 from European Economic and Social Committee: http://eur-lex.europa.eu 
Kinkel, S. (2014). Future and impact of backshoring - Some conclusions from 15 years of research on German practices. Journal of Purchasing and Supply Management, 20(2), 63-65.

Kinkel, S. (2012). Trends in production relocation and backshoring activities. International Journal of Operations \& Production Management, 32(6), 696-720.

Leibl, P., Nischler, C., Morefield, R., \& Pfeiffer, R. (2009). An analysis of off-shoring manufacturing to reduce costs. Journal of Business and Behavioural Sciences, 21(1), 130-139.

Martínez-Mora, C., \& Merino, F. (2014). Offshoring in the Spanish footwear industry: a return journey?. Journal of Purchasing \& Supply Management, 20(4), 225-237.

Mata, J., \& Portugal, P. (2000). Closure and Divestiture by Foreign Entrant: The Impact of Entry and Post-Entry Strategies. Strategic Management Journal, 21(5), 549-562.

Mellahi, K. (2003). The De-internationalization Process: A Case Study of Marks and Spencer. In C. Wheeler, F. McDonald \& I. Greaves (Ed.), Internationalization: Firm Strategies and Management (pp. 150-162). Palgrave Macmillan UK. doi: 10.1057/9780230514638

Mińska-Struzik, E., \& Nowara, W. (2014). Dylematy badań nad internacjonalizacją przedsiębiorstwa. International Business and Global Economy, 33, 394-405.

Młody, M. (2015). Istota i motywy podejmowania przez przedsiębiorstwa strategii reshoringu. Prace Naukowe Wyższej Szkoły Bankowej w Gdańsku, 40, 209-223.

Moradlou, H., \& Backhouse, C. (2015). Re-shoring UK Manufacturing Activities, Supply Chain Management \& Postponement Issues. Paper presented at the 18th Annual Cambridge International Manufacturing Symposium: Capturing value from global networks: implications for manufacturing, supply chains and industrial policy. Retrieved on January 10, 2016 from http://www.ifm.eng.cam.ac.uk

Pearce, J.A. (2014). Why domestic outsourcing is leading America's reemergence in global manufacturing. Business Horizons, 57(1), 27-36.

Porter, M.E. (1976). Please note location of nearest exit: Exit barriers and planning. California Management Review, 19(2), 21-33.

Reiljan, E. (2004). Reasons for de-internationalization: an analysis of Estonian manufacturing companies. Workshop paper on 30th EIBA Annual Conference: Enlarged European Union: Challenges to International Business and Management, Ljubljana.

Simoes, V.C. (2005). Divestment by foreign-based companies: Portuguese experiences. Paper presented at the conference: Relocation of production and jobs to CEE countries - who gains and who loses? Hamburg: Hamburg Institute of International Economics.

Tate, W.L., Ellram, L.M., Schoenherr, T., \& Petersen, K.J. (2014). Global competitive conditions driving the manufacturing location decision. Business Horizons, 57(3), 381-390.

Turcan, R.V. (2011). De-internationalization: A conceptualization. Paper presented at AIB-UK \& Ireland Chapter Conference: International Business: New challenges, new forms, new practices, Edinburgh, United Kingdom.

UNCTAD (2013). World Investment Report 2013: Global Value-Chains: Investment and Trade for Development. New York and Geneva: UNCTAD.

UNCTAD (2014). World Investment Report 2014: Investing in the SDGs: An Action Plan. New York and Geneva: UNCTAD.

Van den Bossche, P., Gupta, P., Gutierrez, H., \& Gupta, A. (2014). Solving the Reshoring Dilemma. Supply Chain Management Review, 18(1), 26-33.

Welch, C., \& Welch, L. (2009). Re-internationalization. Exploration and conceptualisation. International Business Review, 18(6), 567-577. 
Welch, L., \& Luostarinen, R. (1988). Internationalization: Evolution of a Concept. Journal of General Management, 14(2), 34-55.

\section{Author}

\section{Michał Młody}

Assistant Professor at the Poznan University of Economics and Business - Department of Strategic Management. PhD in economics with the specialization in international business (2014). His scientific interests focus on strategic management in international business, international competitiveness and internationalization strategies of companies.

Correspondence to: Dr Michał Młody; Poznan University of Economics and Business, Faculty of Management, Department of Strategic Management; Al. Niepodległości 10, 61-875 Poznań, Poland; e-mail: michal.mlody@ue.poznan.pl

\section{Copyright and License}

This article is published under the terms of the Creative Commons Attribution - NonCommercial - NoDerivs (CC BY-NC-ND 3.0) License

http://creativecommons.org/licenses/by-nc-nd/3.0/

\section{Published by the Centre for Strategic and International Entrepreneurship - Krakow, Poland}

